\title{
Control of pollutants using stand-off pads containing different natural materials
}

\author{
J. LUO, A. DONNISON, C. ROSS, S. LEDGARD and B. LONGHURST \\ AgResearch, Ruakura Research Centre, PB 3123, Hamilton \\ jiafa.1uo@agresearch.co.nz
}

\begin{abstract}
Farmers are increasingly using management systems such as moving cows out of paddocks onto stand-off pads to protect wet soils from damage during winter. Studies were carried out to investigate nutrient and faecal bacterial retention or loss from stand-off pad materials. A preliminary laboratory study found that a range of natural materials, including crushed pine bark, wood chips, zeolite and soil can retain between $66 \%$ and $76 \%$ of applied cows' excreta nitrogen $(\mathrm{N})$. Zeolite was found to be particularly good at reducing ammonia $\left(\mathrm{NH}_{3}\right)$ volatilisation losses from the columns. A field-scale standoff pad study at a Waikato dairy farm, in the winter season of 2005, indicated that carbon (C)-rich materials including both bark and sawdust can be used as standoff pad materials with effective retention of $\mathrm{N}$ and faecal bacteria. Both bark and sawdust pads retained about $60 \%$ of deposited excreta N. Substantially more Escherichia coli were recovered in the drainage from the bark pad (total yield $3.1 \times 10^{11}-$ E. coli) than from the sawdust pad (total yield $7.5 \times 10^{9}$ E. coli) demonstrating that sawdust was more effective than bark in retaining these faecal bacteria.
\end{abstract}

Keywords: stand-off pads, winter management, dairy, nitrogen, faecal bacteria, natural materials

\section{Introduction}

When conditions are wet, grazing animals can cause soil physical damage and affect pasture production. To protect wet soils from damage some dairy farmers are moving cows out of paddocks including temporarily holding them on farm races, using "sacrifice" paddocks, or using specially constructed stand-off pads. These practices will be most successful if they also avoid gaseous losses and prevent the transfer of nutrients and faecal bacteria to the wider environment. Guidelines have been produced for the design and management of stand-off and feed pads (Dexcel 2005). These guidelines state that cows prefer soft surfaces such as woodchips so that they can lie down in comfort. Experimental studies are being carried out to develop effective stand-off pads constructed from natural materials on which cows can stand for extended periods of time when paddocks are not suitable for grazing (Fig.1). Important criteria for our studies were to achieve maximum environmental protection by the use of pad materials that are optimal for retaining nutrients and faecal bacteria from cows' excreta.

There are literature reports of the effectiveness of some materials for nutrient retention that could be potentially used in stand-off pads (e.g. Luo et al. 2004). When cow manure was mixed with pine bark, the bark was found to retain $\mathrm{N}$, reduce gaseous losses including ammonia $\left(\mathrm{NH}_{3}\right)$ and hydrogen sulphide $\left(\mathrm{H}_{2} \mathrm{~S}\right)$ (Luo et al. 2004). This retention of $\mathrm{N}$ may be due to adsorption and/or immobilisation of $\mathrm{N}$ and sulphur (S) (e.g. points 3, 4 and 5 in Fig.1) by the C-rich bark material. Zeolite, an alumino-silicate mineral, has been used to retain cations and anions from wastewater (Nguyen \& Tanner 1998) and may be a useful material to incorporate in pads.

Livestock manures contain a range of enteric microorganisms, some of which are infectious for humans as well as animals (Hutchison et al. 2004a), including Campylobacter (Ross \& Donnison 2003), the most prevalent infectious microorganism in New Zealand. Studies have shown that enteric pathogens decline in stored manure slurry (e.g. Hutchison et al. 2004b) but that they are seldom completely eliminated (Avery et al. 2005) and moisture content is an important factor

Figure 1 Simplified diagram of a stand-off pad system.

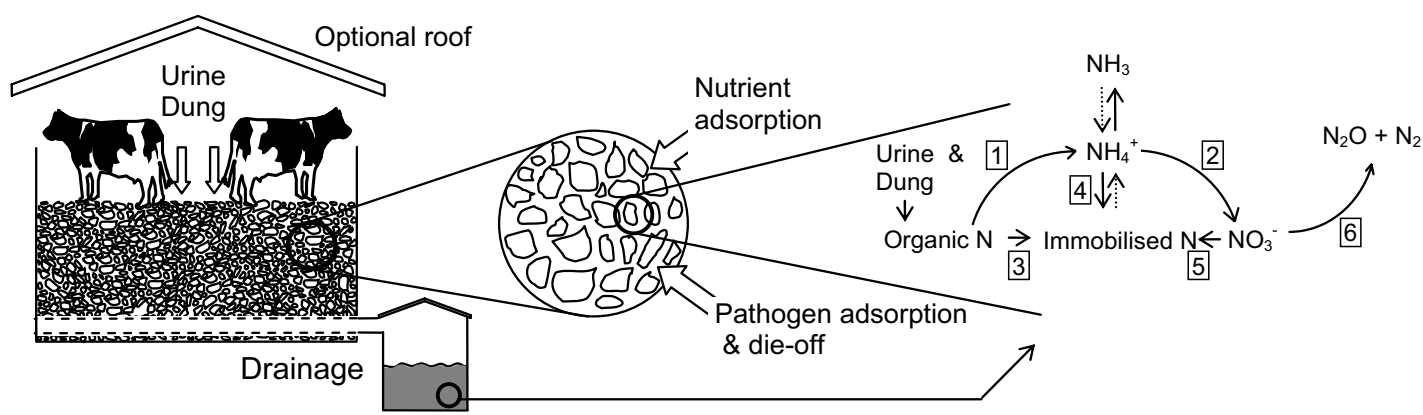


controlling survival (Berry \& Miller 2005). There are few reports of the effects of adding natural materials such as sawdust or wood chips to manure but Miller et al. (2003) tested faecal bacterial survival in pens to which either straw bedding or woodchip bedding was added. These workers found no bactericidal effect which they attributed to a low ratio of bedding to manure. Under wet conditions that generate overland flow, large numbers of microorganisms are transferred from faeces to waterways (Muirhead et al. 2005). A pad design that includes materials that maximise retention of bacteria, together with an efficient drainage collection system could allow time for bacterial die-off outside the soil/plant/water system and prevent transfer to waterways.

The success of stand-off pads depends on the effectiveness of pad materials in continuously retaining nutrients and pathogens. The retention of nutrients means that after the stand-off period, pad materials could be then used as fertiliser or be composted for gardening purposes. To be effective for this purpose, pad materials should be chosen for maximum nutrient retention, to enhance fertiliser value, but guidelines will be needed to ensure that faecal bacterial concentrations have been reduced to minimal levels at the time of use.

The objective of this study was to identify naturally available materials of sufficient supply and with high adsorption potential that would be suitable for use as pad materials. In this paper we present the results of two studies. Firstly a laboratory-scale study that was undertaken to evaluate the capacity of several potential stand-off materials to retain nutrients, particularly $\mathrm{N}$. Secondly we present the results of a field-scale study carried out on a working dairy farm in which we compared two stand-off pads that differed only in their fill material, one being filled with bark and the other with sawdust.

\section{Materials and methods}

\section{Laboratory-scale column study}

The study of nutrient retention by natural materials consisted of 12 columns that were held in a constant temperature $\left(10^{\circ} \mathrm{C}\right)$ laboratory. Each column consisted of tested pad materials contained within an upright 300 $\mathrm{mm}$ tall ' $300 \mathrm{~mm}$ internal diam. high density polyethylene (HDPE) pipe, sealed to a HDPE base plate. The columns were placed on a metal frame, which gave access to the drainage collection system. The rim of the columns extended about $70 \mathrm{~mm}$ above the material surface level to contain applied excreta.

The natural materials used in the column study were untreated pine bark and wood chips, natural zeolite and topsoil. The bark, wood chips, and zeolite had a size range of 4-10 mm. The soil used was Horotiu silt loam
Characteristics of natural materials used in the column study.

\begin{tabular}{lcccc} 
& Soil & Pine bark & Wood chips & Zeolite \\
\hline$(\%)$ & 0.483 & 0.094 & 0.026 & 0 \\
C $(\%)$ & 4.55 & 31.2 & 26.7 & 0 \\
io & 9.4 & 323 & 1027 & 0 \\
& 5.4 & 5.1 & 5.3 & 5.4 \\
\hline
\end{tabular}

(allophanic soil) that had been passed through a $10 \mathrm{~mm}$ screen. There were three replicate columns for each of the four materials. A range of chemical characteristics for these materials are summarised in Table 1.

Cow excreta (1:1 ratio of urine and dung) were applied to the columns every day for 5 weeks. Fresh excreta were collected early in the morning for each application. Samples (approx $100 \mathrm{~g}$ wet weight) were taken, stored and bulked on a weekly basis for chemical analysis. The excreta were applied daily onto the columns at a loading rate of $3.5 \mathrm{~L} / \mathrm{m}^{2}$ in accordance with a typical loading rate over 20 hours produced by the recommended number of cows on a stand-off pad (Dexcel 2003). The total amount of $\mathrm{N}$ applied during the 5 weeks was $403 \mathrm{~g} \mathrm{~N} / \mathrm{m}^{2}$. The columns were retained in the constant temperature laboratory for another 5 weeks to stimulate a likely holding period prior to field use (e.g. land application). After this 5 week period, representative samples were taken from each column for chemical analysis. In order to simulate rainfall, deionized water was added to each column twice a week. Over the 10 weeks of the trial, each column received a total of $330 \mathrm{~mm}$ of deionized water (about $16.5 \mathrm{~mm}$ per application). This amount of water was equivalent to the 75 th percentile from local records for winter rainfall over the past 10 years.

\section{Field-scale stand-off pad study}

Two stand-off pads were constructed in May 2005 at Dexcel's Scott Farm, in the Waikato region. This farm is associated with the Resource Efficient Dairying (RED) farmlet systems trial (Clark 2003). The pads, each $20 \mathrm{~m}$ long, $7.5 \mathrm{~m}$ wide and $0.9 \mathrm{~m}$ deep, and with their own separate drainage system, contained either crushed pine bark (particle size 3-12 mm) or sawdust. Each pad was overlaid with about $0.1 \mathrm{~m}$ depth of coarse bark (particle size 12-25 mm). Pads were used for holding 21 cows for about $18 \mathrm{~h}$ a day during the winter period (31 May to early August) in 2005. Monitoring of pad performance was carried out regularly to determine $\mathrm{N}$ retention in pad materials and $\mathrm{N}$ and faecal bacteria losses into drainage water.

\section{Methods of analysis}

Volatilised ammonia from the laboratory columns over 24 hour periods were collected every week for the first 5 weeks of the trial. The samples were collected 
immediately following the application of excreta. Ammonia volatilisation was measured by placing clear acetate lids on the top of the columns and passing air through the lids. A fixed proportion of the air was then passed through dreshel bottles containing $0.0375 \mathrm{M}$ $\mathrm{H}_{2} \mathrm{SO}_{4}$ to trap any ammonia produced. The acid was analysed for ammonium using colorimetry.

To measure $\mathrm{N}$ in drainage water and natural materials, all drainage water was collected and the volumes recorded in both the column and field studies. Samples of the drainage were stored frozen until analysis. Drainage water was analysed for TKN, $\mathrm{NH}_{4}{ }^{+} \mathrm{N}$ and $\mathrm{NO}_{3}^{-}-\mathrm{N}$ according to standard methods (APHA 1995). At the end of the column study, columns were dismantled and the materials were analysed for the same forms of $\mathrm{N}$. The bark and sawdust materials were also sampled from the field stand-off pads when cows finished using the pads in August 2005, and analysed.

For faecal bacterial analysis, samples of natural materials were homogenised with buffer $(0.1 \%$ peptone plus $0.85 \% \mathrm{NaCl}$ ). Drainage water samples were analysed without processing. Where required, samples were serially diluted in the same buffer. Bacterial analysis was by the five-tube most probable number (MPN) technique. The analytical procedures were those given in MIRINZ Meat Industry Microbiological Methods $4^{\text {th }}$ Edition (AgResearch 2006). Specifically: E. coli was analysed by Method 12.3.3 and Campylobacter by applying a five-tube MPN format to Method 13.1.

\section{Data analysis}

The ammonia emission rates were integrated over time for each column in the laboratory column study to estimate the total emission over the measurement period. Drainage volumes and concentrations of TKN, $\mathrm{NH}_{4}^{+}-\mathrm{N}$, and $\mathrm{NO}_{3}{ }^{-} \mathrm{N}$ were used to calculate cumulative $\mathrm{N}$ in drainage water. Concentrations of $\mathrm{N}$ in materials were used to calculate amounts of cumulative $\mathrm{N}$ in materials. The data collected from the column study were analysed using ANOVA procedure to compare means for different materials. Paired Student's $t$ test was used to compare amounts of faecal bacteria in bark and sawdust pad drainage water.

\section{Results and Discussion Laboratory-scale study}

Cumulative volatilisation losses of $\mathrm{NH}_{3}$ are presented in Table 2. Among the materials examined, zeolite was the most efficient in reducing $\mathrm{NH}_{3}$ loss, and wood chips were the least efficient. The cumulative $\mathrm{NH}_{3}$ volatilisation losses from the columns were in the following order: zeolite $<$ bark $\leq$ soil $\leq$ wood chips. These $\mathrm{NH}_{3}$ losses amounted to about 13\%, 25\%, 30\% and $39 \%$ of the applied excreta $\mathrm{N}$ from columns containing zeolite, bark, soil and wood chips, respectively.

The effects of the different natural materials in reducing drainage $\mathrm{N}$ losses are also presented in Table 2. For columns containing soil, bark and zeolite, most of the losses were occurring when excreta was being applied during the initial 5 weeks. Most of $\mathrm{N}$ in drainage from zeolite, pine bark and wood chips was in the ammonium form (Table 2). Lower $(\mathrm{P}<0.05)$ amounts of $\mathrm{N}$ were found in the drainage from soil columns. After 10 weeks, the cumulative total $\mathrm{N}$ drainage losses from the columns were in the following order: soil $<$ zeolite $\leq$ bark $<$ wood chips. These losses were about $1 \%, 8 \%$, $9 \%$ and $14 \%$ of total excreta $\mathrm{N}$ applied to the columns containing soil, zeolite, bark and wood chips, respectively.

Chemical analyses of materials suggested that significant amounts of $\mathrm{N}$, ranging between $66 \%$ and $76 \%$ of applied excreta, had accumulated in zeolite, bark and soil (Table 2). About 35\% of applied excreta N accumulated in the wood chips. Most of the $\mathrm{N}$ was retained in the top layers $(0-75 \mathrm{~mm})$ of all the materials (data not shown). The analyses also indicated that most of applied excreta $\mathrm{P}, \mathrm{K}$ and $\mathrm{S}$ had accumulated in the bedding materials (data not shown). Some applied excreta $\mathrm{N}$ was not accounted for (Table 2), which was probably largely due to sampling and measurement errors.

The effects of natural materials in retaining N (Table

Table 2 Cumulative $\mathrm{N}$ in $\mathrm{NH}_{3}$ gas loss, drainage and pad materials $\left(\mathrm{g} \mathrm{N} / \mathrm{m}^{2}\right)$ after total application of $403 \mathrm{~g}$ excreta $\mathrm{N} / \mathrm{m}^{2}$ in the column study (numbers in brackets are percent of $\mathrm{N}$ in applied excreta $\mathrm{N}$ ).

\begin{tabular}{|c|c|c|c|c|c|}
\hline & Zeolite & Bark & Soil & Wood chips & $\mathrm{LSD}_{0.05}$ \\
\hline Ammonia $\mathrm{N}$ loss & $53(13)$ & $101(25)$ & $121(30)$ & $157(39)$ & 43 \\
\hline Organic $\mathrm{N}$ in drainage & $6.2(1.5)$ & $7.9(2.0)$ & $2.6(0.6)$ & $11(2.7)$ & 3.5 \\
\hline Ammonium $\mathrm{N}$ in drainage & $24(6.0)$ & $26(6.5)$ & $1.1(0.3)$ & $43(11)$ & 4.6 \\
\hline Nitrate $\mathrm{N}$ in drainage & $u^{1}$ & ud & 0.3 & ud & \\
\hline Cumulative $\mathrm{N}$ in materials & $267(66)$ & $270(67)$ & $305(76)$ & $139(34)$ & 41 \\
\hline Unaccounted for $\mathrm{N}^{2}$ & $53(13)$ & $-1.9(0)$ & $-27(-7)$ & $53(13)$ & \\
\hline
\end{tabular}


2) can be attributed to enhanced microbial $\mathrm{N}$ immobilisation and/or direct absorption of ammonium ions (Bolan et al. 2004; Luo \& Lindsey 2006). Bolan et al. (2004) have also demonstrated that treatment of farm effluent with pine bark achieves a considerable reduction in the $\mathrm{N}$ concentration, which they attributed to immobilisation of $\mathrm{N}$ by the $\mathrm{C}$ - rich bark material $(\mathrm{C}: \mathrm{N}$ ratio $=265: 1)$. Crushed pine bark and zeolite both have large total surface areas and cation exchange capacities (CEC). Ammonium ions, mineralised from cows' excreta, can adsorb onto these surfaces, thereby decreasing the quantity of dissolved ammonium ions and the quantity of equilibrated $\mathrm{NH}_{3}$ gas available for ammonia volatilisation. This was demonstrated by lower $\mathrm{NH}_{3}$ volatilisation losses from bark and zeolite columns, particularly from the zeolite column (Table 2). Sorption of odorous compounds, including $\mathrm{NH}_{3}$ gas, by pine bark and zeolite has also been found to be an important mechanism in removal of odours by biofilters containing mixtures of bark and zeolite (Luo \& Lindsey 2006). As wood chips generally have a smaller surface area than crushed bark they can retain fewer ammonium ions and organic $\mathrm{N}$ compounds, leading to more $\mathrm{N}$ losses through volatilisation and leaching (Table 2). Sawdust has similar properties to wood chips, but has a higher surface area. Therefore, sawdust could be another useful material for stand-off pads to reduce $\mathrm{N}$ losses. Soils can retain large proportions of $\mathrm{N}$ but generally have relatively low porosities and are prone to consolidation over time. These properties of soil can easily result in poor water drainage through the soil columns, and surface ponding could occur during wet winters. Ponding of the soil was observed during this column study. Due to their availability and the ability to retain $\mathrm{N}$, the $\mathrm{C}$-rich materials (including both pine bark and sawdust) were chosen for the field stand-off pad study.

\section{Field-scale study}

The results from the field stand-off pad study showed that both bark and sawdust retained a considerable amount of $\mathrm{N}$ from cows' excreta (Table 3). During the 2005 winter we estimated that about $170 \mathrm{~kg}$ of excreta $\mathrm{N}$ was deposited by the cows on each stand-off pad. However, only about 4\% (6-6.6 $\mathrm{kg} \mathrm{N})$ of the deposited excreta N was collected in the drainage from the pads. Most of the $\mathrm{N}$ in the drainage was in the ammonium form (data not shown). Analyses of both fresh and used materials showed that both sawdust and bark retained about $60 \%$ of the deposited excreta N, most of which was recovered from the top layers. Mass balance calculation indicated that about $35 \%$ of the deposited excreta $\mathrm{N}$ was not accounted for in the pad materials and drainage. Other chemical analyses of materials also indicated that both sawdust and bark retained significant amounts of deposited excreta $\mathrm{P}, \mathrm{K}$ and $\mathrm{S}$ (data not shown). In February 2006, 8 months after commencing use of the pads, there was no indication of any breakdown of the sawdust and bark materials within the pads. The results from the field study (Table 3) confirmed the findings from the column study (Table 2), further suggesting that the C-rich materials (bark and sawdust) can be used as stand-off pad materials for effective retention of $\mathrm{N}$ and other nutrients.

\section{Retention and leaching of faecal bacteria}

Escherichia coli are natural inhabitants of the large intestine of warm blooded animals including dairy cows and are consistently present in dung but not in urine. In this study, 21 cows used both the sawdust and the bark stand-off pads for 18 hours per day from the 31 May to early August 2005. This equated to a total of 664-cow days on each stand-off pad and a daily deposition of about $20 \mathrm{~kg}$ of dung (AgResearch unpublished data) by each cow. The average concentration of $E$. coli in the faeces deposited on the pads was $2.4 \times 10^{8} / \mathrm{kg}$ wet weight giving a calculated total of $3.2 \times 10^{12}$ E. coli deposited on each pad. Drainage was collected and analysed on a weekly basis. More E. coli were consistently recovered in bark pad drainage than in sawdust pad drainage as shown in Figure 2 and this difference was statistically significant $(\mathrm{P}<0.05)$. The total yield of E. coli during this period was $7.5 \times 10^{9} E$. coli in the sawdust pad drainage and $3.1 \times 10^{11} \mathrm{E}$. coli in the bark pad drainage. Using these data, we estimate the retention of $E$. coli to be $99.7 \%$ in the sawdust pad and $90.2 \%$ in the bark pad.

We also measured thermotolerant Campylobacter, a pathogenic faecal bacterial species commonly present in

Table $3 \mathrm{~N}$ balance after 21 cows had been held on stand-off pads in the winter (31 May to early August 2005) of 2005.

\begin{tabular}{|c|c|c|c|c|}
\hline & \multicolumn{2}{|c|}{ Amount (kg N) } & \multicolumn{2}{|c|}{ L Recovery (\%) } \\
\hline & Sawdust & Bark & Sawdust & Bark \\
\hline Deposited excreta $\mathrm{N}$ & 170 & 170 & & \\
\hline Drainage $\mathrm{N}$ & 6.0 & 6.6 & 4 & 4 \\
\hline Accumulative $\mathrm{N}$ in materials & 102 & 103 & 60 & 61 \\
\hline Unaccounted for $\mathrm{N}^{1}$ & 62 & 60 & 36 & 35 \\
\hline
\end{tabular}

${ }^{1}$ Unaccounted for $\mathrm{N}$ was due to gaseous losses and/or errors of sample collection and analysis. 
Figure 2 Recovery of E. coli in the cumulative drainage from the sawdust and the bark stand-off pads over the period (31 May to early August 2005) when 21 cows spent $18 \mathrm{~h}$ per day on the pads.

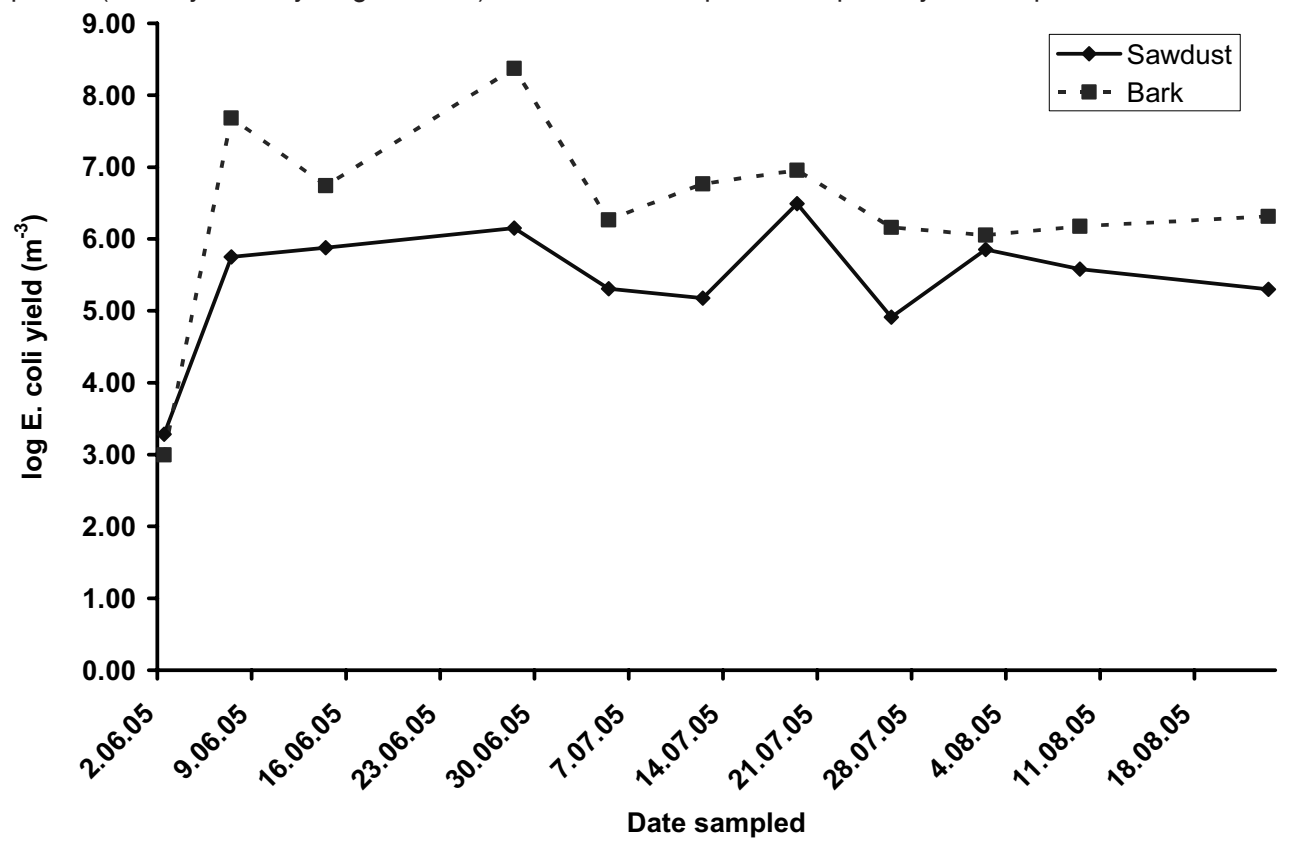

dairy cows, in the drainage from each pad. The total yield was $1.1 \times 10^{7}$ Campylobacter in the bark drainage and $5.5 \times 10^{6}$ Campylobacter in the sawdust drainage. Although these differences are not statistically significant they follow the same pattern as E. coli, i.e. more Campylobacter were leached from the bark than from the sawdust pad.

After the cows were removed from the stand-off pads in August, we continued to collect drainage approximately monthly until 11 November 2005. Over the entire 5month collection period, a total of $103 \mathrm{~m}^{3}$ of drainage was collected from the sawdust pad and $107 \mathrm{~m}^{3}$ from the bark pad. The total yield of $E$. coli in drainage collected after the cows had moved out was $2.1 \times 10^{9} E$. coli from the sawdust pad and $2.9 \times 10^{9} \mathrm{E}$. coli from the bark pad. In contrast to $E$. coli, no Campylobacter were recovered in the drainage from either pad during this period.

Stand-off pads efficiently capture a large proportion of faecal bacteria shed by cows. However, while the pads are in use, substantial numbers of both $E$. coli and Campylobacter are transported to the drainage. The pad materials retained large numbers of faecal bacteria and the continued recovery of $E$. coli in drainage liquid demonstrated that these bacteria remained viable for the two and a half month monitoring period after the cows had been removed.

\section{ACKNOWLEDGEMENTS}

The project was funded by the New Zealand Foundation for Research, Science and Technology. Technological assistance from Mark Boyes, Martin Kear and Weiwen Qiu was appreciated.

\section{REFERENCES}

AgResearch 2006. MIRINZ meat industry microbiological methods 4th edition. Eds. Le Roux, G.; Mills, J.; Donnison, A. http://www.agresearch .co.nz/micromanual/.

APHA 1995. Standard methods for the examination of water and wastewater, 19th edition, American Public Health Association, Washington, D.C.

Avery, L. M.; Killham, K.; Jones, D. L. 2005. Survival of $E$. coli $\mathrm{O} 157: \mathrm{H} 7$ in organic wastes destined for land application. Journal of Applied Microbiology 96: 814-822.

Berry E. D.; Miller, D. N. 2005. Cattle feedlot soil moisture and manure content: II, Impact on Escherichia coli O157. Journal of Environmental Quality 34: 656-663.

Bolan, N.S.; Wang, L.; Adriano, D.C. 2004. Nutrient removal from farm effluents. Bioresource Technology 94: 251-260.

Clark, D. 2003. RED trial measures the effect of feed and management. Dexcelink (Spring 2003). 16 pp.

Dexcel 2005. Minimising muck, maximising money; stand-off and feed pads design and management guidelines. Dexcel, Hamilton. 44 pp.

Hutchison, M.L.; Walters, L.D.; Avery, S.M.; Synge, B.A.; Moore, A. 2004a. Levels of zoonotic agents in British livestock manures. Letters in Applied 
Microbiology 39: 207-214.

Hutchison, M.L.; Walters, L.D.; Moore, A.; Crookes, K.M.; Avery, S.M. 2004b. Effect of length of time before incorporation on survival of pathogenic bacteria present in livestock wastes applied to agricultural soil. Applied and Environmental Microbiology 70: 5111-5118.

Luo, J.; Kulasegarampillai, M.; Bolan, N.; Donnison, A. 2004. Control of gaseous emissions of ammonia and hydrogen sulphide from cow manure by use of natural materials. New Zealand Journal of Agricultural Research 47: 545-556.

Luo, J.; Lindsey, S. 2006. The use of pine bark and natural zeolite as biofilter media to remove animal process odours. Bioresource Technology 97: 1461-1469.
Miller, J.J.; Beasley, B.W.; Yanke, L.J.; Larney, F.J. 2003. Bedding and seasonal effects on chemical and bacterial properties of feedlot cattle manure. Journal and Environmental Quality 32: 1887-1894.

Muirhead, R.W.; Collins, R.P.; Bremer, P.J. 2005. Erosion and subsequent transport state of Escherichia coli from cowpats. Applied \& Environmental Microbiology 71: 2875-2870.

Nguyen, M.L.; Tanner, C.C. 1998. Ammonium removal from wastewaters using natural New Zealand zeolites. New Zealand Journal of Agricultural Research 41: 427-446.

Ross, C.; Donnison, A. 2003. Campylobacter and farm dairy effluent irrigation. New Zealand Journal Agricultural Research 46: 255-262. 